\title{
DAergic Neuronal Dynamics: intrinsic properties, receptor dynamics, and network effects
}

\author{
A Oster ${ }^{1 *}$, B Gutkin ${ }^{2,3}$ \\ From Twenty Second Annual Computational Neuroscience Meeting: CNS*2013 \\ Paris, France. 13-18 July 2013
}

Midbrain dopaminergic neurons send numerous projections to cortical and sub-cortical areas, and, in a manner dependent upon their activities, diffusely release dopamine (DA) to their targets. In particular, in the ventral tegmental area (VTA), the release of dopamine is thought to be associated with reward-related information [1]. The DAergic neurons display a wide range of activity modes varying in frequency and spike distribution, with some cells predominately firing in a tonic fashion while others exhibit burst firing [2]. The variety of activity modes is significant as experimental studies have shown that DAergic neuronal bursting is associated with a greater degree of DA release than an equivalent tonic activity pattern [3]. Here, we introduce a single compartmental, conductancebased computational model for DA cell activity and utilize it to identify mechanisms behind certain activity modes displayed by midbrain DA neurons (in line with experimental findings and other modeling studies). Our model suggests that endogenous burst firing patterns are strongly dependent upon the strength of the SK conductance, the amount of drive, and the amount of GABA inhibition. The model has the property that transient burst firing events can be elicited by an increase in the NMDA conductance, and by sudden decreases of the GABA inhibition. In addition to these findings, we present our current progress on the development of a meta-model for DA cell activity that considers a merging of our conductance-based model with detailed receptor dynamics, mean-field circuit dynamics, and variations in the cortical drive from the prefrontal cortex. We, also, explore how nicotine stimulation leads to an increase in the firing rate and, for certain neurons, an increase in the degree of burst firing.

\footnotetext{
* Correspondence: osteram@gmail.com

'Department of Mathematics, Case Western Reserve University, Cleveland,

$\mathrm{OH}$ 44016, USA

Full list of author information is available at the end of the article
}

\section{Acknowledgements}

The authors would like to thank Mark Humphries (University of Sheffield) and Alexey Kuznetsov (IUPUI) for their suggestions that contributed to the development of this work. Support for this work was provided by: ANR MNP "Dopanic" (BG, AO), NeRF postdoctoral fellowship (AO), CNRS (BG), INSERM $(B G)$, and an ENP collabora- tive grant (BG).

\section{Author details}

${ }^{1}$ Department of Mathematics, Case Western Reserve University, Cleveland, $\mathrm{OH} 44016$, USA. ${ }^{2}$ Group for Neural Theory, Ecole Normale Supérieure, Paris, 75005, France. ${ }^{3}$ Centre National de la Recherche Scientifique, Paris, France.

Published: 8 July 2013

\section{References}

1. Schultz W: Getting formal with dopamine and reward. Neuron 2002, 36(2):241-263

2. Mameli-Engvall M, Evrard A, Pons S, Maskos U, Svensson TH, Changeux J-P, Faure P: Hierarchical control of dopamine neuron-firing patterns by nicotinic receptors. Neuron 2006, 50(6):911-921.

3. Gonon F: Nonlinear relationship between impulse flow and dopamine released by rat midbrain dopaminergic neurons as studied by in vivo electrochemistry. Neuroscience 1988, 24(1):19-28.

doi:10.1186/1471-2202-14-S1-P156

Cite this article as: Oster and Gutkin: DAergic Neuronal Dynamics: intrinsic properties, receptor dynamics, and network effects. BMC Neuroscience 2013 14(Suppl 1):P156.

Submit your next manuscript to BioMed Central and take full advantage of:

- Convenient online submission

- Thorough peer review

- No space constraints or color figure charges

- Immediate publication on acceptance

- Inclusion in PubMed, CAS, Scopus and Google Scholar

- Research which is freely available for redistribution
C Biomed Central

(c) 2013 Oster and Gutkin; licensee BioMed Central Ltd. This is an Open Access article distributed under the terms of the Creative Commons Attribution License (http://creativecommons.org/licenses/by/2.0), which permits unrestricted use, distribution, and reproduction in any medium, provided the original work is properly cited. 